\title{
Heteropoly Acid in Ionic Liquid - An Efficient Catalyst for the Preparation of $2 \mathrm{H}$-Indazolo[2,1-b]Phthalazine-Triones
}

\author{
Razieh Fazaeli ${ }^{*}$, Hamid Aliyan* and Nahid Fazaeli
}

Department of Chemistry, Islamic Azad University, Shahreza Branch, 86145-311, Iran

\begin{abstract}
H$-Indazolo[2,1-b]phthalazine-1,6,11(13H)-trione derivatives were synthesized in a simple and efficient method from the three-component condensation reaction of phthalhydrazide, dimedone, and aromatic aldehydes by $\mathrm{H}_{3} \mathrm{PW}_{12} \mathrm{O}_{40}$ in ionic liquid in good to excellent yields and short reaction times. The ionic liquid 1-butyl-3methylimidazolium tetrafluoroborate $\left([\mathrm{bmim}] \mathrm{BF}_{4}\right)$ offered the best results in terms of yield of the products. It was observed that a homogeneous reaction medium proved beneficial for the yield of the reaction.
\end{abstract}

Keywords: Heteropoly acids (HPAs), dimedone, phthalhydrazide, indazolophtalazine, one-pot reaction, ionic liquid.

\section{INTRODUCTION}

Nitrogen-containing heterocyclic compounds spread out over a large area in nature, and their act of applying to biologically active pharmaceuticals, agrochemicals, and functional materials are becoming to a larger and larger degree important [1]. Phthalazine derivatives were reported to possess vasorelaxant [2], cardiotonic [3], and anticonvulsant [4], activities. Therefore, a number of methods have been reported in the literature for the synthesis of phthalazine derivatives [4-11]. Unfortunately, many of these processes suffer from one or other limitations such as harsh reaction conditions, low product yields, tedious workup procedures, relatively long reaction times, and cooccurrence of several side products, and difficulty in recovery and reusability of the catalysts. Moreover, some of the reagents employed are very expensive. Therefore, the search continues for a better catalyst for the synthesis of heterocycles containing phthalazine ring fragment in term of operational simplicity, reusability, economic viability, and greater selectivity. Recently the synthesis of $2 \mathrm{H}-$ indazolo[2,1-b]phthalazine-triones has been reported by Bazgir and co-workers using $p$-TSA as catalyst [12].

In recent years, the use of ionic liquids as a recyclable reaction medium, to replace volatile organic solvents has received considerable attention [13]. Ionic liquids, also called "the designer solvents", have been largely successful in replacing obnoxious organic solvents. Their high thermal stability and ability to solvate various substrates have made them highly useful in a variety of organic reactions [14-16].

In recent decades, uses of heteropoly acids (HPAs) as catalysts for fine organic synthetic processes have been developed and are important for industries related with fine chemicals [17], including flavors, pharmaceuticals and food industries [18]. Heteropoly acids are more active catalysts than conventional inorganic and organic acids for various

*Address correspondence to these authors at the Department of Chemistry, Islamic Azad University, Shahreza Branch, 86145-311, Iran; Tel: +98 321 3232706; Fax: +98 $3213232701-2$;

E-mails: fazaeli@iaush.ac.ir, aliyan@iaush.ac.ir reactions in solutions [19]. They are used as industrial catalysts for several liquid phase reactions [20-23]. Among heteropoly acids, polytungstic acids are the most widely used catalysts owing to their high acid strengths, thermal stabilities, and low reducibilities. Catalysts based on heteropoly acids as Brønsted acids have many advantages over liquid acid catalysts. They are non-corrosive and environmentally benign, presenting fewer disposal problems. Solid heteropoly acids have attracted much attention in organic synthesis owing to easy work-up procedures, easy filtration, and minimization of cost and waste generation due to reuse and recycling of the catalysts [24-26]. Supported heteropoly acid on silica gel has been used as effective catalyst for Diels Alder [27] and Fries rearrangement [28], Friedel-Crafts reactions [29].

In continuation of our work on the catalytic properties of heteropoly acids [30], herein, we wish to report a suitable method for the use of $\mathrm{H}_{3} \mathrm{PW}_{12} \mathrm{O}_{40}$ in ionic liquid as catalyst for Preparation of 2,2-dimethyl-13-phenyl-2,3-dihydro-1Hindazolo[2,1-b]phthalazine-4,6,11(13H)-trione (Scheme 1).

\section{RESULT AND DISCUSSION}

At first, for optimization of the reaction conditions, the reaction of benzaldehyde $(1.2 \mathrm{mmol})$, dimedone $(1 \mathrm{mmol})$ and phthalhydrazide $(1 \mathrm{mmol})$ in $\mathrm{CH}_{3} \mathrm{CN}$ at room temperature in the presence of a catalytic amount of $\mathrm{H}_{3} \mathrm{PW}_{12} \mathrm{O}_{40}(5 \mathrm{~mol} \%)$ was studied. The analysis of the reaction mixture showed that the desired product 2,2dimethyl-13-phenyl-2,3-dihydro-1H-indazolo[2,1-b]phthalazine-4,6,11(13H)-trione was produced in only $75 \%$ after $3 \mathrm{~h}$ plus unreacted starting materials (Table 1, entry 1 ). We have also observed that even the prolonged reaction time to $7 \mathrm{~h}$ did not affect the yield of the product. Then, we decided to study the catalytic ability of $\mathrm{H}_{3} \mathrm{PW}_{12} \mathrm{O}_{40}$ in ionic liquid. We observed that the reaction of benzaldehyde $(1.2 \mathrm{mmol})$ dimedone $(1 \mathrm{mmol})$ and phthalhydrazide $(1 \mathrm{mmol})$ in $\mathrm{CH}_{3} \mathrm{CN}$ in the presence of the $\mathrm{H}_{3} \mathrm{PW}_{12} \mathrm{O}_{40}(2 \mathrm{~mol} \%)$ in ionic liquid 1-butyl-3-methylimidazolium tetrafluoroborate $\left([\mathrm{bmim}] \mathrm{BF}_{4}\right)$ was performed smoothly and the desired product; 2,2-dimethyl-13-phenyl-2,3-dihydro-1H-indazolo[2, 1-b]phthalazine-4,6,11(13H)-trione was obtained in $92 \%$ 

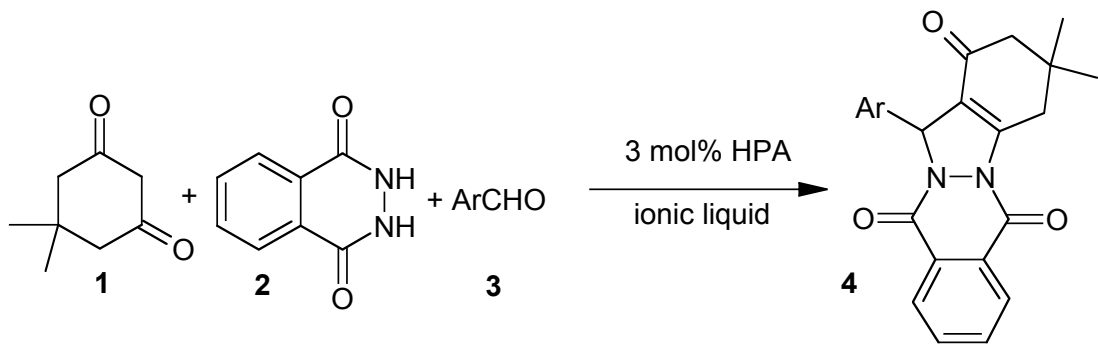

Scheme 1. Preparation of 2,2-dimethyl-13-phenyl-2,3-dihydro-1H-indazolo[2,1-b]phthalazine-4,6,11(13H)-trione.

yield after $30 \mathrm{~min}$ (Table 1, entry 6). We have also studied the similar reaction only in the presence of ionic liquid ([bmim $\left.] \mathrm{BF}_{4}\right)$. The reaction did not proceed at all and the starting materials were remained intact after $10 \mathrm{~h}$ (Table 1, entry 9). These results show the strong synergistic effect of ionic liquid upon the catalytic activity of $\mathrm{H}_{3} \mathrm{PW}_{12} \mathrm{O}_{40}$ in the reaction of benzaldehyde with dimedone and phthalhydrazide.

We carried out the reaction in various other hydrophilic as well as hydrophobic ionic liquids and conventional organic solvents to compare the outcome of the reaction in terms of the yield and the rate of the reaction. HPA dissolved in organic solvents like DMF, and acetonitrile and hydrophilic ionic liquids, such as 1-butyl-3-methylimidazolium chloride $([\mathrm{bmim}] \mathrm{Cl})$ to produce a homogenous system. However, HPA was insoluble in hydrophobic ionic liquids, such as 1-butyl-3-methylimidazolium hexafluorophosphate $\left([\mathrm{bmim}] \mathrm{PF}_{6}\right)$. Better yields were obtained when catalyst was soluble in the reaction medium compared with those obtained when the catalyst was insoluble in the reaction solvent (Table 1, entries 6,7). From these observations, it can be deduced that the solubility of the catalyst in the medium plays an important role in enhancing the outcome of the reaction and that a homogeneous system produces better yields. Amongst the various ionic liquids and organic solvents that were employed for the present study, [bmim $] \mathrm{BF}_{4}$ was employed for further investigation.

Table 1. Phosphotungstic Acid (HTP) Catalyzed Preparation of 2,2-Dimethyl-13-Phenyl-2,3-Dihydro-1H-Indazolo [2,1-b]Phthalazine-4,6,11(13H)-Trione in Various Solvents at Room Temperature ${ }^{\mathrm{a}}$

\begin{tabular}{|c|c|c|c|}
\hline Entry & Solvent & Time (h) & Yield $^{\mathbf{b}}(\mathbf{\%})$ \\
\hline \hline $\mathbf{1}$ & Acetonitrile & 3 & 75 \\
\hline $\mathbf{2}$ & Ethanol & 5 & 43 \\
\hline $\mathbf{3}$ & Water & 7 & 28 \\
\hline $\mathbf{4}$ & Dichloromethane & 5.5 & 40 \\
\hline $\mathbf{5}$ & DMF & 9 & 55 \\
\hline $\mathbf{6}$ & {$\left[\mathrm{bmim}_{\mathrm{BF}}{ }_{4}\right.$} & 0.5 & 92 \\
\hline $\mathbf{7}$ & {$\left[\mathrm{bmim}_{\mathrm{PF}}\right.$} & 8 & 80 \\
\hline $\mathbf{8}$ & {$[\mathrm{bmim}] \mathrm{Cl}_{6}$} & 3.5 & 90 \\
\hline $\mathbf{9}$ & {$\left[\mathrm{bmim}_{\mathrm{B}} \mathrm{BF}_{4}{ }^{\mathrm{c}}\right.$} & 10 & no reaction \\
\hline
\end{tabular}

${ }^{a}$ Reaction conditions: benzaldehyde $(1.2 \mathrm{mmol})$, dimedone $(1 \mathrm{mmol})$, phthalhydrazide ( $1 \mathrm{mmol})$, and HTP $(2 \mathrm{~mol} \%)$ was used in various solvents $(5 \mathrm{ml})$ at room temperature. ${ }^{\mathrm{b}}$ Isolated yields. ${ }^{\mathrm{c}}$ Without HTP.
The results of the synthesis of 3,4-dihydro-3,3-dimethyl13-phenyl-2H-indazolo[2,1-b]phthalazine-1,6,11(13H)-trione (4a) using a variety of heteropolyacids as catalyst in [bmim] $\mathrm{BF}_{4}$ are shown in Table 2. We employed four different HPAs, $\mathrm{H}_{3} \mathrm{PW}_{12} \mathrm{O}_{40}, \mathrm{H}_{3} \mathrm{PMo}_{12} \mathrm{O}_{40}, \mathrm{H}_{4} \mathrm{SiW}_{12} \mathrm{O}_{40}$, $\mathrm{H}_{4} \mathrm{SiMo}_{12} \mathrm{O}_{40}$ (Keggin series) for the reaction. All the HPAs completely dissolved in the ionic liquid. $3 \mathrm{~mol} \%$ of each of these HPAs were used. The reaction mixture was stirred at room temperature. Comparison of these HPAs showed that the higher activity and selectivity could be achieved using $\mathrm{H}_{3} \mathrm{PW}_{12} \mathrm{O}_{40}$. This catalyst is more efficient than others and gave the highest yield of the desired product. Comparison of the obtained yields of all reactions at the same time, $20 \mathrm{~min}$, confirmed this result (Table 2).

Table 2. Comparison of Different Heteropoly Acids (HPAs) Employed for Preparation of 2,2-Dimethyl-13Phenyl-2,3-Dihydro-1H-Indazolo[2,1-b]Phthalazine$4,6,11(13 H)$-Trione in $[\mathrm{bmim}] \mathrm{BF}_{4}$ at Room Temperature After 20 Min $^{\mathrm{a}}$

\begin{tabular}{|c|c|c|}
\hline Heteropoly Acid $^{\mathbf{a}}$ & Catalyst (Mol \%) & Yield $^{\mathbf{b}}(\mathbf{\%})$ \\
\hline \hline $\mathrm{H}_{3} \mathrm{PW}_{12} \mathrm{O}_{40}$ & 1 & 78 \\
\hline $\mathrm{H}_{3} \mathrm{PW}_{12} \mathrm{O}_{40}$ & 3 & 98 \\
\hline $\mathrm{H}_{3} \mathrm{PW}_{12} \mathrm{O}_{40}$ & 5 & 98 \\
\hline $\mathrm{H}_{3} \mathrm{PMo}_{12} \mathrm{O}_{40}$ & 3 & 74 \\
\hline $\mathrm{H}_{4} \mathrm{SiW}_{12} \mathrm{O}_{40}$ & 3 & 75 \\
\hline $\mathrm{H}_{4} \mathrm{SiMo}_{12} \mathrm{O}_{40}$ & 3 & 68 \\
\hline
\end{tabular}

${ }^{a}$ Reaction conditions: benzaldehyde $\left(\begin{array}{lllll}1.2 & \mathrm{mmol}\end{array}\right)$, dimedone $(1 \mathrm{mmol})$ and phthalhydrazide $(1 \mathrm{mmol})$ was used in various catalysts in $[\mathrm{bmim}] \mathrm{BF}_{4}(2 \mathrm{~mL})$ at room temperature. ${ }^{\mathrm{b}}$ Isolated yields.

In order to show the general applicability of the protocol, we have applied this catalytic system for the preparation of $2 H$-indazolo[2,1- $b]$ phthalazine-1,6,11(13H)-trione derivatives from several types of aldehydes. Aromatic aldehydes carrying either electron donating or withdrawing substituents afforded high product yields with high purity (Table 3, entries $4 \mathrm{a}-\mathrm{e})$ with exception of the electron donating methyl group (Table 3, entry 4f), which takes a slightly longer reaction time.

In order to show the merit of the present work in comparison with recently reported protocols, we compared the results of the $2 H$-indazolo $[2,1-b]$ phthalazine1,6,11(13H)-trione derivatives synthesis from various aldehydes in the presence of silica- $\mathrm{SO}_{3} \mathrm{H}, p$-TSA, and $\mathrm{HTP} /[\mathrm{bmim}] \mathrm{BF}_{4}$ with respect to the amounts of the catalysts used, reaction times and yields of the products (Table 4). 
Table 3. Preparation of $2 \mathrm{H}-$ Indazolo[2,1-b]Phthalazine-1,6,11(13H)-Trione Derivatives $4^{\mathrm{a}}$

\begin{tabular}{|c|c|c|c|c|c|}
\hline Entry & Substrate & Product & Time (min) & Yield $(\%)^{b}$ & m.p. (lit. m.p.) ${ }^{\text {ref }}$ \\
\hline $\mathbf{a}$ & & & 10 & 90 & $203-205(203-205)^{10}$ \\
\hline b & & & 7 & 87 & $223-225(226-228)^{10}$ \\
\hline c & & & 7 & 92 & $265-267(266-268)^{10}$ \\
\hline d & & & 8 & 92 & $261-263(261-263)^{10}$ \\
\hline e & & & 7 & 90 & $218-220(218-220)^{10}$ \\
\hline f & & & 18 & 82 & $227-229(226-228)^{10}$ \\
\hline
\end{tabular}

${ }^{a}$ Reaction conditions: aldehyde $(1.2 \mathrm{mmol})$, dimedone $(1 \mathrm{mmol})$, phthalhydrazide $(1 \mathrm{mmol})$, and mixture of $[\mathrm{bmim}] \mathrm{BF}_{4}(2 \mathrm{~mL})$ and $\mathrm{HTP}(3 \mathrm{~mol} \%)$, room temperature.

Comparison of Keggin type heteropoly acid with these catalysts for this reaction show that activity of $\mathrm{HTP} /[\mathrm{bmim}] \mathrm{BF}_{4}$ seems to be higher than or equal with other known catalysts (Table 4).

The combination of the heteropoly acid and $[\mathrm{bmim}] \mathrm{BF}_{4}$ provides a homogeneous system for the reaction; hence this prompted us to investigate the possibility of recycling the complete system of HPA and ionic liquid. The result was quite fruitful. The entire product could be isolated from the reaction mixture simply by ether extraction, and the system of the catalyst and ionic liquid could be recovered and recharged with fresh substrates. We screened the system for three subsequent runs; the product was obtained in $98 \%$, $96 \%$ and $87 \%$ yields, respectively (Table 5).

\section{EXPERIMENTAL}

All solvents and reagents were purchased from Fluka, Aldrich and Merck chemical Companies. The products were purified by column or thick layer chromatography techniques. Products were characterized by comparison of spectroscopic data (IR, ${ }^{1} \mathrm{H}$ NMR spectra) and melting points with authentic samples. FT-IR spectra were recorded on a Shimadzu DR-8001 spectrometer. NMR spectra were recorded on a Brucker Avance DPX 250MHzinstrument. 
Table 4. Comparison of HTP/[bmim] $\mathrm{BF}_{4}$ with Two Catalysts for Synthesis of $2 H$-Indazolo[2,1-b]Phthalazine-1,6,11(13H)-Trione Derivatives

\begin{tabular}{|c|c|c|c|c|}
\hline Entry & Aldehyde (Ar) & \multicolumn{3}{|c|}{ Time (min): Yield (\%) } \\
\hline 2 & 4- $\mathrm{NO}_{2}-\mathrm{C}_{6} \mathrm{H}_{4}$ & $7: 87$ & $7: 85$ & $10: 91$ \\
\hline 3 & 4-Br- $\mathrm{C}_{6} \mathrm{H}_{4}$ & $7: 92$ & $7: 86$ & $10: 90$ \\
\hline
\end{tabular}

Mass spectra were recorded on a Shimadzu GC-MS-QP 1000PX. Melting points are not corrected.

Table 5. Recycling of HTP ${ }^{a}$

\begin{tabular}{|c|c|}
\hline Run & Yield $^{\mathbf{b}} \mathbf{( \% )}$ \\
\hline \hline 1 & 98 \\
\hline 2 & 96 \\
\hline 3 & 87 \\
\hline 4 & 51 \\
\hline
\end{tabular}

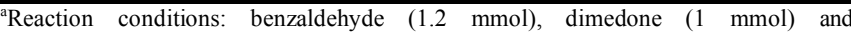
phthalhydrazide $(1 \mathrm{mmol}), \mathrm{HTP}(3 \mathrm{~mol} \%),\left[\mathrm{bmim}^{\mathrm{B}} \mathrm{BF}_{4}(2 \mathrm{~mL})\right.$, room temperature. ${ }^{\mathrm{b}}$ Isolated yields.

Typical Procedure for the Preparation of $2 \mathrm{H}$-Indazolo [2,1-b]Phthalazine-1,6,11(13H)-Trione Derivatives 4

To a mixture of ionic liquid $(2 \mathrm{~mL})$ and phosphotungstic acid $(3 \mathrm{~mol} \%)$, dimedone $(0.14 \mathrm{~g}, 1 \mathrm{mmol})$, phthalhydrazide $(0.16 \mathrm{~g}, 1 \mathrm{mmol})$ and an aldehyde $(1.2 \mathrm{mmol})$ were added. The resulting mixture was stirred at room temperature for the appropriate time as indicated in Table 3 . The progress of the reaction was monitored by TLC. The crude product was isolated by extracting the reaction mixture with diethyl ether $(4 \times 15 \mathrm{ml})$. The combined ether extractions were dried over $\mathrm{Na}_{2} \mathrm{SO}_{4}$, concentrated and the residue recrystallized from ethyl acetate/ $n$-hexane $(1: 3)$ to afford the pure product. The products $4 \mathrm{a}-4 \mathrm{f}$ are known compounds, and their structures were deduced by comparison of their physical and spectroscopic data with those previously reported [9-12].

Spectroscopic Data for 3,4-Dihydro-3,3-Dimethyl-13-(Phenyl)2H-Indazolo[2,1-b]Phthalazine-1,6,11(13H)-Trione (4a)

Yellow powder. $\mathrm{Mp} 203-205^{\circ} \mathrm{C}$; IR $(\mathrm{KBr})\left(v_{\max }, \mathrm{cm}^{-1}\right)$ : $2953,1565,1573 ; \delta_{\mathrm{H}}\left(300 \mathrm{MHz}, \mathrm{CDCl}_{3}\right) 1.21(3 \mathrm{H}, \mathrm{s}), 1.23(3 \mathrm{H}$, s), $2.35(2 \mathrm{H}, \mathrm{s}), 3.25$ and $3.40(2 \mathrm{H}, \mathrm{AB}$ system $), 6.45(1 \mathrm{H}, \mathrm{s})$, 7.29-8.35 $(9 \mathrm{H}, \mathrm{m}) ; \delta_{\mathrm{C}}\left(75 \mathrm{MHz}, \mathrm{CDCl}_{3}\right)$ 28.5, 28.8, 34.6, 38.1, 50.9, 64.9, 118.6, 127.2, 127.7, 127.9, 128.6, 128.9, 129.2, 133.6, 134.5, 136.4, 150.9, 154.3, 156.2, 192.2; MS, $m / z(\%): 372\left(\mathrm{M}^{+}\right.$, 15), 295 (100), 104 (84), 76 (67). Anal. Calcd for $\mathrm{C}_{23} \mathrm{H}_{20} \mathrm{~N}_{2} \mathrm{O}_{3}: \mathrm{C}$, 74.18; H, 5.41; N, 7.52\%. Found: C, 74.10; H, 5.16; N, 7.46\%.

Spectroscopic Data for 3,4-Dihydro-3,3-Dimethyl-13-(4Nitrophenyl)-2H-Indazolo[2,1-b]Phthalazine-1,6,11(13H)Trione (4b)

Yellow powder. $\mathrm{Mp} 223-225^{\circ} \mathrm{C}$; IR $(\mathrm{KBr})\left(v_{\max }, \mathrm{cm}^{-1}\right)$ : 2922, 1692, 1647, 1610; $\delta_{\mathrm{H}}\left(300 \mathrm{MHz}, \mathrm{CDCl}_{3}\right) 1.21(3 \mathrm{H}, \mathrm{s})$, $1.24(3 \mathrm{H}, \mathrm{s}), 2.33(2 \mathrm{H}, \mathrm{s}), 3.25$ and 3.41 ( $2 \mathrm{H}, \mathrm{AB}$ system),
$6.50(1 \mathrm{H}, \mathrm{s}), 7.60-8.43(8 \mathrm{H}, \mathrm{m}) ; \delta_{\mathrm{C}}\left(75 \mathrm{MHz}, \mathrm{CDCl}_{3}\right) 28.4$, $28.7,34.7,38.2,50.8,64.4,117.3,124.3,127.6,128.2$, $128.3,128.6,128.9,134.0,134.9,143.1,147.9,151.9,154.7$, 155.7, 192.3.

Spectroscopic Data for 3,4-Dihydro-3,3-Dimethyl-13-(4-Bromophenyl)-2H-Indazolo[2,1-b]Phthalazine-1,6,11(13H)-Trione (4c)

Yellow powder. $\mathrm{Mp} 265-267^{\circ} \mathrm{C}$; IR $(\mathrm{KBr})\left(v_{\max }, \mathrm{cm}^{-1}\right)$ : 2958, 1543, 1618; $\delta_{\mathrm{H}}\left(300 \mathrm{MHz}, \mathrm{CDCl}_{3}\right) 1.21(3 \mathrm{H}, \mathrm{s}), 1.22$ $(3 \mathrm{H}, \mathrm{s}), 2.34(2 \mathrm{H}, \mathrm{s}), 3.24$ and $3.42(2 \mathrm{H}, \mathrm{AB}$ system $), 6.41$ $(1 \mathrm{H}, \mathrm{s}), 7.29-8.37(8 \mathrm{H}, \mathrm{m}) ; \delta_{\mathrm{C}}\left(75 \mathrm{MHz}, \mathrm{CDCl}_{3}\right)$ 28.4, 28.9, $34.6,38.0,50.9,64.3,118.1,122.9,127.8,128.1,128.8$, $128.8,129.1,131.7,133.7,134.7,135.4,151.3,154.1,156.2$, 192.2 .

Spectroscopic Data for 3,4-Dihydro-3,3-Dimethyl-13-(4Chlorophenyl)-2H-Indazolo[2,1-b]Phthalazine-1,6,11(13H)Trione (4d)

Yellow powder. Mp $261-263{ }^{\circ} \mathrm{C}$; IR $(\mathrm{KBr})\left(v_{\max }, \mathrm{cm}^{-1}\right)$ : 2952, 1652, 1628; $\delta_{\mathrm{H}}\left(300 \mathrm{MHz}, \mathrm{CDCl}_{3}\right) 1.23(3 \mathrm{H}, \mathrm{s}), 1.25$ $(3 \mathrm{H}, \mathrm{s}), 2.32(2 \mathrm{H}, \mathrm{s}), 3.26$ and $3.44(2 \mathrm{H}, \mathrm{AB}$ system $), 6.44$ $(1 \mathrm{H}, \mathrm{s}), 7.33-8.36(8 \mathrm{H}, \mathrm{m}) ; \delta_{\mathrm{C}}\left(75 \mathrm{MHz} \mathrm{CDCl}_{3}\right) 28.4,28.9$, $34.9,38.1,50.9,64.6,118.2,127.7,128.2,128.4,128.8$, $128.9,129.2$, 133.4 134.5, 134.5, 151.3, 154.3, 156.0, 192.0.

Spectroscopic Data for 3,4-Dihydro-3,3-Dimethyl-13-(4Fluorophenyl)-2H-Indazolo[2,1-b]Phthalazine-

\section{1,6,11(13H)-Trione (4e)}

Yellow powder. Mp $218-220^{\circ} \mathrm{C}$; IR $(\mathrm{KBr})\left(v_{\max }, \mathrm{cm}^{-1}\right)$ : $2951,1668,1660 ; \delta_{\mathrm{H}}\left(300 \mathrm{MHz}, \mathrm{CDCl}_{3}\right) 1.20(3 \mathrm{H}, \mathrm{s}), 1.22$ $(3 \mathrm{H}, \mathrm{s}), 2.35(2 \mathrm{H}, \mathrm{s}), 3.24$ and $3.43(2 \mathrm{H}, \mathrm{AB}$ system $), 6.43$ $(1 \mathrm{H}, \mathrm{s}), 8.34(8 \mathrm{H}, \mathrm{m}) ; \delta_{\mathrm{C}}\left(75 \mathrm{MHz}, \mathrm{CDCl}_{3}\right) 28.4,28.5,34.5$, $38.1,50.9,64.4,115.5,115.9,118.3,127.2,128.2,128.9$, 129.2, 132.1, 133.8, 134.6, 151.4, 154.2, 156.2, 192.0.

Spectroscopic Data for 3,4-Dihydro-3,3-Dimethyl-13-(4-Methylphenyl)-2H-Indazolo[2,1-b]Phthalazine-1,6,11(13H)-Trione (4f)

Yellow powder. Mp $227-229^{\circ} \mathrm{C}$; IR $(\mathrm{KBr})\left(v_{\max }, \mathrm{cm}^{-1}\right)$ : 2954, 1659, 1628; $\delta_{\mathrm{H}}\left(300 \mathrm{MHz}, \mathrm{CDCl}_{3}\right) 1.21(3 \mathrm{H}, \mathrm{s}), 1.23$ $(3 \mathrm{H}, \mathrm{s}), 2.30(3 \mathrm{H}, \mathrm{s}), 2.35(2 \mathrm{H}, \mathrm{s}), 3.24$ and $3.42(2 \mathrm{H}, \mathrm{AB}$ system), $6.43(1 \mathrm{H}, \mathrm{s}), 7.13-8.35(8 \mathrm{H}, \mathrm{m}) ; \delta_{\mathrm{C}}(75 \mathrm{MHz}$, $\left.\mathrm{CDCl}_{3}\right)$ 21.3, 28.9, 34.7, 38.2, 50.9, 64.6, 118.9, 127.0, $127.5,127.9,129.2,129.0,129.1,133.3,133.4,134.5,138.5$, $150.5,154.3,156.0,192.4$.

\section{CONCLUSIONS}

We have described an efficient and one-pot synthesis of $2 H$-indazolo[2,1-b]phthalazine-triones via a cyclocondensation reaction of dimedone, phthalhydrazide, and aromatic 
aldehydes using a combination of heteropoly acid and ionic liquid under solvent-free conditions. Both the catalyst and ionic liquid could be easily recovered and recycled. The absence of undesirable side-products and ambient reaction conditions also enhanced the synthetic utility of the reaction.

\section{ACKNOWLEDGEMENTS}

We gratefully thank Islamic Azad University, Shahreza Branch for financial support.

\section{REFERENCES}

[1] (a) Franklin, E. C. Heterocyclic nitrogen compounds. I. pentacyclic compounds. Chem. Rev., 1935, 16(3), 305-361. (b) Bergstrom, F.W. Heterocyclic nitrogen compounds. Part IIA. hexacyclic compounds: pyridine, quinoline, and isoquinoline. Chem. Rev., 1944, 35(2), 77-277.

[2] Grasso, S.; DeSarro, G.; Micale, N.; Zappala, M.; Puia, G.; Baraldi, M.; Demicheli, C. Synthesis and anticonvulsant activity of novel and potent 6,7-methylenedioxyphthalazin-1(2H)-ones. J. Med. Chem., 2000, 43(15), 2851-59.

[3] Nomoto, Y.; Obase, H.; Takai, H.; Teranishi, M.; Nakamura, J.; Kubo, K. Studies on cardiotonic agents. II. synthesis of novel phthalazine and 1,2,3-benzotriazine derivatives. Chem. Pharm. Bull. (Tokyo) 1990, 38(8), 2179-83.

[4] Watanabe, N.; Kabasawa, Y.; Takase, Y.; Matsukura, M.; Miyazaki, K.; Ishihara, H.; Kodama, K.; Adachi, H. 4benzylamino-1-chloro-6-substituted phthalazines: synthesis and inhibitory activity toward phosphodiesterase. J. Med. Chem., 1998, 41(18), 3367-72.

[5] Sheradsky, T.; Moshenberg, R. Bridgehead hydrazines. 3. Unusual photorearrangement of 1,4-diphenylpyridazino[1,2-b]phthalazine6,11-dione. J. Org. Chem., 1986, 51(16), 3123-25.

[6] Heine, H.W.; Baclawski, L.M.; Bonser, S.M.; Wachob, G.D. Diaziridines. 5. Reaction of some 1-aroyl- and 1,2diacyldiaziridines. J. Org. Chem., 1976, 4l(20), 3229-32.

[7] Ramtohup, Y. K.; James, M.N.G.; Vederas, J.C. Synthesis and evaluation of keto-glutamine analogues as inhibitors of hepatitis A virus 3C proteinase. J. Org. Chem., 2002, 67(10), 3169-78.

[8] Liu, L. P.; Lu, J. M.; Shi, M. PhI(OAc) 2 -mediated novel 1,3-dipolar cycloaddition of methylenecyclopropanes (MCPs), vinylidenecyclopropanes (VCPs), and methylenecyclobutane (MCB) with phthalhydrazide. Org. Lett., 2007, 9(7), 1303-06.

[9] Csampai, A.; Kormendy, K.; Ruff, F. Chain length dependent reactivity of 2-( $\omega$-hydroxyalkyl)-4-( $\omega$-hydroxyalkylamino)phthalazin-1(2h)-ones in azeotropic hydrobromic acid. Tetrahedron, 1991, $47,4457-64$

[10] Shaterian, H. A.; Ghashang, M.; Feyzi, M. Silica sulfuric acid as an efficient catalyst for the preparation of $2 \mathrm{H}$-indazolo[2,1b]phthalazine-trione. Appl. Catal. A., 2008, 345, 128-33.

[11] Hwang, J. Y.; Choi, H.S.; Gong, Y.D. Solid-phase synthesis of $[1,2,4]$ triazolo $[3,4-a]$ phthalazine and tetrazolo[ $[5,1-a]$ phthalazine derivatives. Tetrahedron Lett., 2005, 46, 3107-3110.

[12] Sayyafi, M.; Seyyedhamzeh, M.; Khavasi, H. R.; Bazgir, A. Onepot, three-component route to $2 H$-indazolo[2,1-b]phthalazinetriones. Tetrahedron, 2008, 64, 2375-78.

[13] Welton, T. Room-temperature ionic liquids. solvents for synthesis and catalysis. Chem. Rev., 1999, 99, 2071-2084.

[14] Dupont, J.; de Souza, R.F.; Suarez, P. A. Z. Ionic liquid (Molten Salt) phase organometallic catalysis. Chem. Rev., 2002, 102, 36673692 .
[15] Lee, S.-G.; Park, J. H.; Kang, J.; Lee, J. K. Lanthanide triflatecatalyzed three component synthesis of $\alpha$-amino phosphonates in ionic liquids. A catalyst reactivity and reusability study. Chem. Commun., 2001, 1698-1699.

[16] Rasalkar, M. S.; Bhilare, S. V.; Deorukhkar, A. R.; Darvatkar, N. B.; Salunkhe, M. M. Heteropoly acid in ionic liquid - An efficient and recyclable system for one-pot three-component Mannich reaction. Can. J. Chem., 2007, 85, 77-80.

[17] Kozhevnikov, I.V.; In: Derouane, E.; Ed., Catalysts for Fine Chemical Synthesis, Catalysis by Polyoxometalates 2; Wiley, New York, 2002.

[18] Okuhara, T.; Mizuno, N.; Misono, M. Catalytic chemistry of heteropoly compounds. Adv. Catal., 1996, 41, 113-252.

[19] Drago, R. S.; Dias, J. A.; Maier, T. An acidity scale for brönsted acids including $\mathrm{H}_{3} \mathrm{PW}_{12} \mathrm{O}_{40}$. J. Am. Chem. Soc., 1997, 119(33), 7702-10.

[20] Ono, Y.; Thomas, J. M.; Zamaraev, K.I.; Eds., Perspectives in Catalysis; Blackwell, London, 1992, p. 341.

[21] Kozhevnikov, I. V.; Matveev, K. I. Homogeneous catalysts based on heteropoly acids. Appl. Catal., 1983, 5 (2), 135-50.

[22] Izumi, Y.; Urabe, K.; Onaka, A. Zeolite, Clay and Heteropolyacids in Organic Chemistry; Kodansha/VCH, Tokyo/Weinheim, 1992, $\mathrm{p}$ 99.

[23] Kozhevnikov, I.V. Heteropoly acids and related compounds as catalysts for fine chemical synthesis. Catal. Rev. Sci. Eng., 1995, $37,311-52$

[24] Schwegler, M. A.; Bekkum, H.; Munck, N. Heteropolyacids as catalysts for the production of phthalate diesters. Appl. Catal. A, 1991, 74, 191-204.

[25] (a) Fazaeli, R.; Tangestaninejad, S.; Aliyan, H. Solvent-free and selective tosylation of alcohols and phenols with p-toluenesulfonic chloride by heteropoly acids as highly efficient catalysts. Can. $J$. Chem., 2006, 84, 812-18. (b) Fazaeli, R.; Aliyan, H.; Tangestaninejad, S. Aluminum dodecatungstophosphate promoted synthesis of 1'5-benzodiazepine derivatives under solvent-free conditions. Heterocycles, 2007, 71, 805-14.

[26] Meuzelaar, G.; Maat, L.; Sheldon, R.; Kozhevnikov, I.V. Heteropoly acid-catalyzed diels-alder reactions. Catal. Lett., 1997, $45,249-51$

[27] Kozhevnikova, E. F.; Rafiee, E.; Kozhevnikov, I.V. Fries rearrangement of aryl esters catalysed by heteropoly acid: catalyst regeneration and reuse. Appl. Catal. A, 2004, 260, 25-34.

[28] Isumi, Y.; Hisano, K.; Hida, T. Acid catalysis of silica-included heteropolyacid in polar reaction media. Appl. Catal. A, 1999, 181, 277-82.

[29] Mao, J.; Nakajo, T.; Okuhara, T. Alkylation-Acylation of Aromatics with $\gamma$-Butyrolactone Catalyzed by Heteropolyacids Supported on Silica. Chem. Lett., 2002, 11, 1104-1105.

[30] (a) Fazaeli, R.; Tangestaninejad, S.; Aliyan, H.; Moghadam, M. One-pot synthesis of dihydropyrimidinones using facile and reusable polyoxometalate catalysts for the Biginelli reaction. Appl. Catal. A, 2006, 309, 44-51. (b) Fazaeli, R.; Tangestaninejad, S.; Aliyan, H. Highly efficient conversion of aldehydes to geminal diacetates (solvent-free) and their deprotection using facile and reusable molybdenum and tungsten polyoxometalates. Appl. Catal. A, 2007, 318, 218-26. (c) Fazaeli, R.; Aliyan, H. Clay (KSF and K10)-supported heteropoly acids: Friendly, efficient, reusable and heterogeneous catalysts for high yield synthesis of 1,5benzodiazepine derivatives both in solution and under solvent-free conditions. Appl. Catal. A, 2007, 331, 78-83. 